\title{
A REAFFIRMATION: THE AUTHENTICITY OF THE ROBERTS MEMORANDUM, OR FELIX THE NON-FORGER
}

\author{
RICHARD D. FRIEDMAN†
}

In the December 1955 issue of this Law Review, Justice Felix Frankfurter published a tribute to his late friend and colleague, Owen J. Roberts. ${ }^{1}$ The tribute centered on what Frankfurter claimed was the text of a memorandum that Roberts wrote in 1945 to explain his conduct in the critical minimum wage cases of 1936 and 1937, Morehead v. New York ex rel. Tipaldo ${ }^{2}$ and West Coast Hotel Co. v. Parrish. ${ }^{3}$ Scholars have often challenged the adequacy of Roberts's account of why he cast decisive votes for the conservatives in Tipaldo and for the liberals in West Coast Hotel. ${ }^{4}$ Until recently, however, no scholar has doubted that what Frankfurter published was, in fact, Roberts's account. But now, in an article published by the Harvard Law Review, Professor Michael Ariens makes the remarkable suggestion that Frankfurter-"Felix the Cat," Ariens calls him-fabricated the document. ${ }^{5}$ The suggestion is demonstrably

† Thanks for their helpful comments to Michael Ariens, Bill Leuchtenburg, and Bill Miller, and especially to John Chambers and Ed Purcell.

${ }^{1}$ See Felix Frankfurter, Mr. Justice Roberts, 104 U. PA. L. REv. 311 (1955).

2298 U.S. 587 (1936).

300 U.S. 379 (1937).

4 See, e.g., Leo Pfeffer, ThIS Honorable Court: A History of the UnIted STATES SUPREME CouRT 317-20 (1965); John W. Chambers, The Big Switch: Justice Roberts and the Minimum-Wage Cases, 10 LAB. Hist. 44, 67 (1969); Michael E. Parrish, The Great Depression, the New Deal, and the American Legal Order, 59 WASH. L. REv. 723, 732 (1984).

${ }^{5}$ See Michael Ariens, A Thrice-Told Tale, or Felix the Cat, 107 HARv. L. REv. 620, 645-49 (1994). I refer to the proposition as a "suggestion" to ensure fairness to Ariens, who does not expressly assert that Frankfurter fabricated the memorandum. Ariens puts the point more softly, saying, "I have several reservations concerning the existence of this memorandum." Id. at 645. But he presents at length reasons that, in his view, point to the conclusion that Frankfurter fabricated the memorandum. See id. at 645-49. And this conclusion, in my view, is essential to the broader argument of his article. See infra notes $43-44$ and accompanying text. Indeed, Ariens says at one point: "Roberts was a foil, a maguffin whom Frankfurter used for the Court's benefit. The memorandum was 'ambiguous and contrived,' but for reasons that have little to do with Roberts." Id. at 664 (quoting, in part, Chambers, supra note 4, at 67). But I do not believe the memorandum can be "ambiguous and contrived" for reasons having "little to do with Roberts" if Roberts wrote the memorandum. In any event, whether Ariens contends or merely suggests fabrication by Frankfurter, he has clearly raised the possibility. The purpose of this essay is to show that the possibility is baseless. 
false. It should be put aside and forgotten.

If Roberts did not write the memorandum, then Frankfurter, by fabricating a text and presenting it as Roberts's, committed extraordinary misconduct. So far as I am aware, no one has ever charged Frankfurter with such flagrant misfeasance-and Frankfurter was not without foes. We must therefore approach Ariens's suggestion with a large dollop of skepticism. ${ }^{6}$ And that skepticism should survive what appears at first glance to be Ariens's strongest piece of evidence-the missing evidence, the fact that the memorandum cannot now be found. Even without additional evidence, I believe we should be inclined to suppose that some factor other than fabrication by Frankfurter accounts for our present inability to find the memorandum. And, in fact, there are two additional compelling pieces of evidence that make the fabrication hypothesis implausible.

First, Professor John W. Chambers, an historian, saw the Roberts memorandum in the collection of Frankfurter papers at the Library of Congress in the 1960s. In an article published in 1969, Chambers reported on his search for material that might help explain Roberts's votes in the minimum wage cases. He wrote in a footnote:

There are now ... copies of several letters from Roberts in four folders of the Felix Frankfurter papers which were deposited last year at the Library of Congress. Although the original letters are located in Frankfurter's Supreme Court papers at the library of the Harvard Law School, photocopies of the Roberts-Frankfurter correspondence from 1930-55 are included in Box 33 of the Washington collection. Disappointingly, the letters are mainly

${ }^{6}$ See, e.g., Letter from Bennett Boskey, Esq. to Erwin N. Griswold, Esq. (Feb. 28, 1994) (noting "what I remember so well about FF-who, notwithstanding his many superlative qualities, may not have been a saint but certainly was not a forger") (on file with author). Dean Griswold responded:

Those of us who knew FF were aware that he had his enthusiasms and crotchets. But we also knew that he was a remarkable man of extraordinary ability and that he never manufactured a story like this. With personal knowledge of the man, and long and close contact with him, as you and I both had, it is quite beyond belief that it would be seriously suggested that he did so.

Letter from Erwin N. Griswold, Esq. to Bennett Boskey, Esq. (Mar. 8, 1994) (on file with author). Mr. Boskey has told me that, at the time of this correspondence, neither he nor Dean Griswold knew of Chambers's finding of the memorandum. See Telephone Interview with Bennett Boskey, Esq. (May 18, 1994) (notes on file with author). 
chatty notes about life on Roberts's Chester County, Pennsylvania, farm and shed no new light on his action in the minimum wage cases. $^{7}$

So far, no good. But this sentence immediately follows: "Included is the original three-page typescript of Roberts's memorandum to Frankfurter addressed 'To you in confidence/O.J.R.' and dated '11$9-45^{\prime}$ but it only testifies to the accuracy of the reproduction in the University of Pennsylvania Law Review." 8

To his credit, Ariens cites the Chambers piece. But he does not quote this passage. Instead, he says that Chambers "searched the Frankfurter Papers inconclusively for the original or a copy of the memorandum." I must confess that as I read Chambers's language it makes his discovery of the original of the memorandum sound very conclusive indeed. Ariens does acknowledge that this language "suggests that Chambers located the memorandum." 10 But, says Ariens, "[ $t]$ he language is quite vague" (I have another confession: the ambiguity escaped me) "and on close inspection, it appears that at most what he found was a copy of something that seemed to be the memorandum."11 I do not think Chambers's language is subject to the interpretation that the memorandum is one of the pieces of correspondence of which he only saw a photocopy. The language is precise: what he saw was both "the original" and a "typescript." Nor could Chambers have been referring to what Ariens did find in the Frankfurter papers-"a typescript copy of unsigned, undated material in the draft of the tribute [by Frankfurter to Roberts] that is identical to the published memorandum."12 Once again, Chambers is gratifyingly precise: what he saw bore the initials of Owen J. Roberts and the date, November 9, 1945, that Frankfurter claimed for the memorandum in his tribute.

Luckily, though, we do not have to rely on interpretation of Chambers's 1969 language. Chambers himself, a young man in 1969 , is not an old man now. As a professor of history at Rutgers University, he is easy to find. ${ }^{13}$ And, I have learned, he is accessible and gregarious and has an excellent memory. Ariens made a

${ }^{7}$ Chambers, supra note 4 , at 64 n.96.

${ }^{8}$ Id.

${ }^{9}$ Ariens, supra note 5, at 648.

${ }^{10} \mathrm{Id}$. at $648 \mathrm{n} .146$.

"Id.

${ }^{12} I d$.

is See AMERICAN Historical AsSOCIATION, DIRECTORY OF HISTORY DEPARTMENTS AND ORganizations in the UNITEd STATES AND CANADA 338 (19th ed. 1993). 
remarkable canvass of former law clerks, law review editors, and others (including me!) who might be thought to have seen the memorandum. ${ }^{14}$ "No one with whom I have spoken," he reports, "remembers ever seeing the original memorandum." 15 But he never spoke to Chambers, the one identified living person who-at least arguably-did claim to have seen the original memorandum.

Chambers says in 1994 that his 1969 language meant exactly what it says, and that it was accurate: he saw the original typescript-not a printed copy, not a photocopy, not a mimeograph-of the memorandum, bearing Roberts's initials and the date, in the Frankfurter collection at the Library of Congress in $1968 .^{16}$ His note of disappointment with respect to the memorandum was not attributable to a failure to find, or uncertainty as to whether he had found, the original of the memorandum. Rather, he was disappointed by his failure to find any useful surrounding correspondence that might have explained how Roberts came to write the memorandum or what Frankfurter thought of it at the time. ${ }^{17}$ The original memorandum itself was not particularly useful to him. It "only testifie[d] to the accuracy of the reproduction" in this Law Review, and that merely confirmed what he had assumed. ${ }^{18}$

Chambers is a highly reputable, well-trained historian. ${ }^{19} \mathrm{He}$ had no apparent motive to substantiate falsely the existence of the memorandum; ${ }^{20}$ on the contrary, a legitimate discovery that Frankfurter had fabricated the memorandum would have been quite a coup for an aspiring scholar. Undoubtedly, it would have led to

${ }^{14}$ See Ariens, supra note 5, at 648 n.147.

${ }^{15} \mathrm{Id}$. at 648.

${ }^{16}$ See Letter from John W. Chambers, Professor of History, Rutgers University, to the author (Mar. 21, 1994) (on file with author); Letter from John W. Chambers to Fred Bauman, Manuscript Division, Library of Congress (Mar. 21, 1994) (on file with author).

${ }^{17}$ See Letter from John W. Chambers to the author, supra note 16.

${ }^{18}$ Id.; see also Telephone Interviews with John W. Chambers (Mar. 14 \& 15, 1994) (notes on file with author).

${ }^{19}$ See Letter from William E. Leuchtenburg, William Rand Kenan Professor of History, University of North Carolina, Adjunct Professor of Legal History, Duke University School of Law, to the author (May 10, 1994) (calling Chambers "a man of impeccable character, thoroughly reliable and trustworthy in every respect") (on file with author); Telephone Interview with Sidney Fine, Andrew Dickson White Professor of History, University of Michigan (March 16, 1994).

${ }^{20}$ Chambers's article was not friendly to Roberts, and was dubious about the explanation given by Roberts in the memorandum. See Letter from John $W$. Chambers to the author, supra note 16 (stating that "my argument is directly against that put forward in the memorandum"). 
publication in a highly visible academic journal. ${ }^{21}$

But if Chambers saw the memorandum in the Frankfurter papers in 1969, why is it not there now? That, unfortunately, is easy to answer, with the second crucial piece of evidence. There was a major theft, or perhaps multiple thefts, from the collection of Frankfurter papers at the Library of Congress in 1972. This theft was widely publicized the next year, ${ }^{22}$ and it is carefully explained in the Library's finding aid to the Frankfurter collection. ${ }^{23}$ Presumably, the theft escaped Ariens's notice; in any event, he does not mention it.

Thus, we have reliable testimony that the memorandum was in the Frankfurter papers in the 1960s, and indisputable proof that there was a major theft from those papers in 1972. I think the overwhelmingly probable explanation for the absence of the memorandum in the 1990s is quite obvious: the memorandum was among the papers stolen.

This after-the-fact account should be enough to dispose of any suspicion that the memorandum was fabricated. And yet the account might not be ultimately satisfying without some understanding of how Roberts came to write the memorandum in the first place. I believe we can reconstruct the story with some confidence.

By the time Roberts retired in 1945, Frankfurter was on very bad terms with Hugo Black ${ }^{24}$ and concerned about what he perceived as Black's dominance over Justices Douglas and Murphy. ${ }^{25}$ Shortly

${ }^{21}$ After a diligent search, Chambers has been unable to find any notes or photocopies from his research on the 1969 article-not surprising given that he has "moved a dozen times since then." Letter from John W. Chambers to the author (May 27, 1994) (on file with author).

${ }_{22}$ See Jack Anderson, Scholar Steals Frankfurter Papers, WASH. POST, Sept. 14, 1973, at D21; Frankfurter Notes Believed Stolen by Capilal Scholar, N.Y. TimES, Sept. 15, 1973, at 5.

${ }^{23}$ See Library of Congress, MATERIAL Missing from the Felix Frankfurter PAPERS 1-4 (n.d.). The Library had not made an item-by-item index of the collection before the theft. Hence, although the Library has listed some of the stolen items (a list that does not include the Roberts memorandum), it cannot create a comprehensive list of all items stolen. See id. at 2; Telephone Interview with Carolyn Sung, former Head of Reference Services, Library of Congress Manuscript Division (Mar. 10, 1994); Telephone Interview with Mary Wolfskill, Library of Congress Manuscript Division (Mar. 10, 1994).

${ }^{24}$ See JAMES F. SIMON, THE ANTACONISTS 158-59 (1989) (noting that Frankfurter would discuss with Roberts Black's "vehemence" and "ruthlessness").

${ }^{25}$ See Felix Frankfurter, From the DiARIES OF FELIX FrankfuRTER 176 (Joseph P. Lash ed., 1975) (complaining in January 1943 that Black, Douglas, and Murphy-"the Axis"-were "hunting in packs" and that Black "controls three votes out of nine in all important matters"). 
after Roberts retired, Frankfurter got into a terrible wrangle with Black, and to some extent with other members of the Court, over the phrasing of a proposed letter to Roberts. Harlan Stone, by then Chief Justice, circulated a draft that included a sentence saying that Roberts had made "fidelity to principle [his] guide to decision." Black struck that sentence and said he would not sign a letter including it. Frankfurter learned of this and hit the roof. $\mathrm{He}$ claimed that Black was in effect denying Roberts "the basic requirements of judicial character." 27 The incident reached a rather dramatic denouement in October at one of the first conferences of the new term, when Frankfurter made quite a nasty scene. The result-ironically in accordance with Roberts's expressed wish ${ }^{28}$ was that the Court sent no letter to Roberts.

According to Frankfurter, Roberts "gave" him the memorandum on November 9, 1945 ${ }^{29}$-barely one month after this fight reached its climax. The fight over the farewell letter concerned, though in general terms, precisely the issue that the memorandum and Frankfurter's tribute addressed-Roberts's "fidelity to principle. ${ }^{n 30}$

${ }^{26}$ Draft Letter from Chief Justice Stone to Justice Roberts (n.d.), microformed on Felix Frankfurter Papers, Harvard Law School Library, at pt. III, reel 4 (Univ. Publications of Am., Inc.) [hereinafter Harvard Frankfurter Papers]. I have in my possession photocopies sent by Frankfurter to Paul Freund in 1958 and passed on to me by Professor Freund in 1991.

${ }^{27}$ Letter from Justice Frankfurter to Chief Justice Stone (Sept. 7, 1945) (photocopy on file with author).

${ }^{28}$ Justice Roberts had earlier told Frankfurter that he wanted Frankfurter to prevent the Court from issuing any encomium letter. See Letter from Justice Roberts to Justice Frankfurter (Oct. 12, 1944), microformed on Harvard Frankfurter Papers, supra note 26, at pt. III, reel 3; see also Ariens, supra note 5, at $635 \mathrm{n.86}$ (quoting, in part, Roberts's letter). Frankfurter evidently ignored that request. As Professor Ariens notes, Roberts wrote to Frankfurter again in 1947 in an attempt to prevent a memorial service because he still dreaded the prospect of hypocritical praise, even if posthumous. Roberts recalled that he had "reposed a trust" in Frankfurter and, without being willing to say that Frankfurter "betrayed that trust," he thought that Frankfurter might be characterized as having "miserably failed," presumably because Frankfurter did not summarily stifle any discussion of a farewell letter. Ariens, supra note 5, at 646 n.139.

${ }^{29}$ Frankfurter, supra note 1, at 314 n.*. Professor Ariens argues that it is unlikely that Roberts and Frankfurter met face-to-face on November 9, 1945. See Ariens, supra note 5, at 646-47. But whether they did or not is of no significance with respect to the authenticity of the memorandum. The notation on the front of the memorandum, reported by Professor Chambers, suggests that indeed Roberts "gave" the memorandum to Frankfurter without the two actually being face-to-face at the time, and that there was no accompanying correspondence. Roberts may very well have mailed the memorandum to Frankfurter. Alternatively, Roberts may have sent the memorandum to Frankfurter by messenger; as Ariens himself notes, Roberts had recurrent business in Washington during this period. See id. at 647 n.142.

${ }^{30}$ Professor Ariens, in dismissing this account of the origin of the memorandum, 
In light of this background, it is not at all surprising that Frankfurter promptly urged Roberts to write a memorandum defending his integrity. Nor is it astonishing that Roberts agreed, after "not a little persuasion," according to Frankfurter." Roberts's distaste for hypocritical praise from others does not make it implausible that he would discreetly aid in his own defense when subjected to what he deemed to be ignorant and unwarranted attacks.

argues that "there is no statement in the tribute along the lines of, 'He made fidelity to principle his guide to decision." Ariens, supra note 5, at 646 n.140. True, Frankfurter did not use language of that sort. But the entire tenor of the tribute is that Roberts had acted on principle. Indeed, Ariens's basic point is that Frankfurter presented the tribute to show that "Roberts' votes were based on principle, not politics," a point that would help "preserve the role of the Court as a principled decisionmaker." Id. at 625; see also id. at 664 ("I am convinced . . . that Frankfurter published the memorandum less to defend Roberts and more to reassert the Supreme Court's independence from politics and thereby to enhance the Court's reputation.").

Professor Ariens's other reasons for rejecting this account are no more persuasive. He points out that "Frankfurter's correspondence to Freund in $\mathbf{1 9 5 8}$ suggested that this episode showed why he denigrated Stone. It was not given to Freund to defend Roberts." Id. at 646 n.140. That is true, but plainly irrelevant: in 1958, Frankfurter's purpose in sending Freund the correspondence relating to the proposed letter to Roberts appears to have been to show why he thought ill of Stone, but that has nothing to do with why Frankfurter asked Roberts to write the memorandum in 1945. In any event, Frankfurter plainly did not have to defend Roberts to Freund in 1958; Freund presumably had read the tribute and the memorandum.

Next, Professor Ariens argues, "Frankfurter believed that this episode [relating to the proposed letter] was another example of Black's unfitness to serve on the Supreme Court. Nothing in Frankfurter's 1945 diary mentions the Roberts valedictory letter episode, ${ }^{n}$ though the diary does mention what Frankfurter believed was Black's improper refusal to recuse himself in an important case. Id. Ariens does not mention that this is the only diary entry for 1945. See FRANKFURTER, supra note 25, at 262. I do not perceive the relevance of this point. That Frankfurter believed the dispute over the letter revealed grave flaws in Black in no way undercuts, and may even support, the likelihood that, in light of that dispute, Frankfurter thought it important for Roberts to record his account of the minimum wage cases.

Finally, Professor Ariens argues that "there is neither a direct nor an indirect attack on either Black or Stone in the Roberts tribute, which I would have expected if there were a connection between the memorandum and the failed letter episode." Ariens, supra note 5, at 646 n.140. But of course one could not really expect Frankfurter to have used the tribute to Roberts to make a public attack, even a veiled one, on Black, one of his colleagues at the time. (Stone does not enter in here because he was willing to speak of Roberts's "fidelity to principle" and had indeed drafted the sentence doing that; Frankfurter's objection to Stone's conduct was that Stone had mishandled the episode and caved in to Black.) In any event, members of the Court were not the only critics of Roberts-and far from the most direct or open critics-to whom the tribute and the memorandum responded.

${ }^{31}$ Frankfurter, supra note 1 , at 314. 
It is thus easy enough to understand how the memorandum might have come into being just as Frankfurter indicated in the tribute. ${ }^{32}$ By contrast, there is no persuasive explanation of why Frankfurter would fabricate the memorandum if Roberts had not written it.

Ariens's thesis is that Frankfurter's publication of the purported memorandum "was only incidentally a defense of Justice Roberts" and "primarily an effort to protect the Court's authority to interpret the Constitution at a time when Brown [v. Board of Education] threatened to compromise that authority. ${ }^{\text {33 }}$ Certainly Frankfurter was motivated to defend the Court in light of Brown. How much defending Roberts's actions nearly two decades earlier would assist in defending the contemporary Court is far less clear. And even if he felt a political need to defend Roberts, it is highly dubious that Frankfurter, a man with a reputation to protect, would be willing to go so far as to fabricate a document. ${ }^{34}$ But let us make assumptions thus far in favor of Ariens's argument-that Frankfurter believed the Court's reputation in the mid-1950s would be substantially assisted by defending Roberts's conduct in the crucial minimum wage decisions of the 1930 s, and that his scruples would not prevent him from fabricating a document if he felt that doing so would help the Court's reputation. And let us even assume that Frankfurter had the ability to forge a document that would later fool Professor Chambers. It still appears that Frankfurter would have had little reason to fabricate the Roberts memorandum.

For one thing, if Frankfurter were disposed to deceit, he might as well have fabricated a conversation with Roberts-a tactic that would have been impossible to detect, given the relationship between the two men-rather than a document, supposedly written nearly a decade after the events described, that sooner or later some relentless researcher would expect, but fail, to find. Furthermore, the memorandum contained easily detectable factual errors. ${ }^{35}$ If

32 Professor Ariens suggests that Frankfurter was cagey and evasive with the editors of this Law Review in discussing the origin of the memorandum. See Ariens, supra note 5, at 647 . It does not strike me that Frankfurter was cagey, or that he had anything to be evasive about, but if he was, it might have been because the memorandum emerged out of the fracas over the proposed letter.

${ }^{33} \mathrm{Id}$. at 624-25.

${ }^{34}$ See Felix Frankfurter Reminisces 217 (Harlan B. Phillips ed., 1960) (recounting A. Lawrence Lowell's comment on the exchange between Frankfurter and John Henry Wigmore over the Sacco-Vanzetti case: "Wigmore is a fool! Wigmore is a fool! He should have known that Frankfurter would be shrewd enough to be accurate!").

${ }^{35}$ The memorandum misstated the procedural posture of West Coast Hotel. See 
Frankfurter were to fabricate a memorandum, it seems unlikely that he would undercut its credibility by incorporating such errors in it.

Beyond this, the memorandum added only interstitially to facts that were easily determinable by the time it was published. ${ }^{36}$ Indeed, Erwin Griswold, in his own tribute to Roberts, published simultaneously with Frankfurter's in this Law Review (but written without Griswold's having seen Frankfurter's), reconstructed essentially the same account as that provided in the memorandum. ${ }^{37}$ Well before Frankfurter published the memorandum, Merlo Pusey published his biography of Chief Justice Hughes. Relying on Hughes's own then-unpublished account, Pusey told a story perfectly consistent with, though less detailed than, that of the memorandum. ${ }^{38}$ Frankfurter, of course, was familiar with Pusey's Pulitzer Prize winning biography-as Ariens mentions, he reviewed the book in the New York Times of November 18, 1951. ${ }^{39}$ Indeed, Ariens himself, showing characteristic resourcefulness, has examined on microform Frankfurter's own copy of Pusey's work, and found that Frankfurter made liner notes squaring perfectly with the

Richard D. Friedman, Switching Time and Other Thought Experiments: The Hughes Court and Constitutional Transformation, 142 U. PA. L. REV. 1891, 1947-48 (1994). It also asserted incorrectly that in West Coast Hotel the State of Washington argued that the Adkins case should be overruled. See id. at 1948-49.

${ }^{36}$ One of Roberts's principal assertions in the memorandum was that he had refused to vote to uphold the statute in Tipaldo because counsel for the State sought disingenuously to distinguish Adkins v. Children's Hospital, 261 U.S. 525 (1923). That the majority opinion in Tipaldo purported to treat Adkins as unchallenged was manifest on the face of the opinion. See 298 U.S. 587, 604-05 (1936) (asserting that "[t]he validity of the principles upon which [Adkins] rests is not challenged").

Perhaps the main point of Roberts's memorandum was that the timing of the events in West Coast Hotel precluded the possibility that his vote was cast under pressure created by the Court-packing battle of 1937. That the Court had noted probable jurisdiction in West Coast Hotel in October 1936, and held arguments in the case in December, with conference and voting presumably soon to follow, was also apparent from the public record. See Friedman, supra note 35, at 1948-49 \& nn.287, 295-96.

${ }^{37}$ See Erwin N. Griswold, Owen J. Roberts as a Judge, 104 U. PA. L. REv. 332, 340-42 (1955). Ariens points out that "Frankfurter may have been aware of Griswold's tribute before he penned his own tribute to Roberts." Ariens, supra note 5, at 637 n.93. That possibility, of course, does not undermine the point I am making here, that the account published in the memorandum was knowable without any assistance from Frankfurter. If anything, the possibility that Frankfurter saw Griswold's tribute before publishing his own only strengthens the point that Frankfurter had little motivation to fabricate a document: why do a dishonest day's work when Dean Griswold was already accomplishing much the same result honestly?

${ }^{38}$ See 2 Merlo J. PuSEY, Charles EvanS Hughes 757 (1951).

${ }^{39}$ See Felix Frankfurter, The Impact of Charles Evans Hughes, N.Y. TIMEs, Nov. 18, 1951 , at 151 . 
account provided in the memorandum. ${ }^{40}$ Ariens is in a quandary "whether the liner notes were supposed to become part of the effort to set the record straight, or whether they were notes designed to present a plausible explanation of Roberts's actions. ${ }^{\text {41 }}$ This last point makes the strain in Ariens's argument quite apparent. Is it not highly probable that Frankfurter's liner notes were just what they appear to be-private notes, written well before Brown and intended, at least during his lifetime, for no one's eyes but his own, containing his understanding of the facts?

What the memorandum did add to facts previously known publicly was Roberts's subjective explanation of his motivations. But this explanation is essentially the same as the one Roberts gave Pusey in a 1946 interview reported by Pusey in $1983 .{ }^{42}$ To the extent that Frankfurter knew about Pusey's interview, it undercuts any possible incentive he might have had to fabricate the memorandum; to the extent he did not, it further corroborates (as if further proof were necessary) the authenticity of the memorandum.

I do not believe that the authenticity of the Roberts memorandum can be reasonably doubted any longer. Given this, Ariens's broader thesis, that publication of the memorandum had more to do with Brown than with Roberts, loses much of its interest. Given what we know of Frankfurter's character, ${ }^{43}$ it is no surprise at all that, in persuading Roberts to write the memorandum, Frankfurter was not motivated solely by the desire to protect the reputation of his friend for "fidelity to principle"; I have argued that the timing of the memorandum strongly suggests that Frankfurter was also motivated in significant part by antipathy to Black and his allies. Nor is it at all surprising that, in both securing the memorandum and publishing it, one of Frankfurter's motivations may have been the support that it gave to the Court's legitimacy. ${ }^{44}$ It is also

${ }^{40}$ See Ariens, supra note 5, at 651 .

${ }^{41} I d$.

42 See Merlo J. Pusey, Justice Roberts' 1937 Turmaround, 1983 Y.B. SUP. CT. HIST. SOC'Y 102, 106.

${ }^{43}$ See H.N. Hirsch, The ENIGMa OF FELIX FrankfurTer 209-10 (1981) (speaking of Frankfurter's "lifelong pattern of intense conflict with an individual or group of individuals he identified as enemies, and the degree to which he thrilled at the chance to defeat them, ${ }^{n}$ and his self-deception as to his own motivations).

11 See FRANKFURTER, supra note 25, at 264 (quoting Frankfurter in 1946: "Of all earthly institutions this Court comes nearest to having, for me, sacred aspects."); SIMON, supra note 24, at 254 (quoting Frankfurter's retirement letter, referring to the Court as "the institution whose concerns have been the absorbing interest of my life”); Albert M. Sacks, Felix Frankfurter, in 3 THE JUSTICES OF THE UNITED STATES 
natural to suppose that this legitimacy-aiding benefit of publishing the memorandum appeared especially strong to Frankfurter given the fortuity that Brown had been decided shortly before. But clearly Brown had nothing to do with the origin of the memorandum; Roberts wrote the memorandum long before Brown was on the horizon. Nor is there any support for the proposition that, in publishing the memorandum, Frankfurter was primarily motivated by Brown: he published it at the most natural time, within months after Roberts's death.

In some respects, as $I$ argue in the companion article to this essay, the memorandum was maddeningly incomplete, inaccurate, and self-serving. But it was what Frankfurter presented it asRoberts's own account, years after the fact, of his conduct in the minimum wage cases. 
